\title{
Trace metal distribution in pristine permafrost-affected soils of the Lena River delta and its hinterland, northern Siberia, Russia
}

\author{
I. Antcibor ${ }^{1}$, A. Eschenbach ${ }^{1}$, S. Zubrzycki ${ }^{1}$, L. Kutzbach ${ }^{1}$, D. Bolshiyanov ${ }^{2}$, and E.-M. Pfeiffer ${ }^{1}$ \\ ${ }^{1}$ Institute of Soil Science, KlimaCampus, Hamburg University, Hamburg, Germany \\ ${ }^{2}$ State Research Center - Arctic and Antarctic Research Institute, St. Petersburg, Russia
}

Correspondence to: I. Antcibor (julia.antsibor@uni-hamburg.de)

Received: 20 December 2012 - Published in Biogeosciences Discuss.: 6 February 2013

Revised: 15 November 2013 - Accepted: 26 November 2013 - Published: 2 January 2014

\begin{abstract}
Soils are an important compartment of ecosystems and have the ability to buffer and immobilize substances of natural and anthropogenic origin to prevent their movement to other environment compartments. Predicted climatic changes together with other anthropogenic influences on Arctic terrestrial environments may affect biogeochemical processes enhancing leaching and migration of trace elements in permafrost-affected soils. This is especially important since Arctic ecosystems are considered to be highly sensitive to climatic changes as well as to chemical contamination. This study characterises background levels of trace metals in permafrost-affected soils of the Lena River delta and its hinterland in northern Siberia $\left(73.5-69.5^{\circ} \mathrm{N}\right)$, representing a remote region far from evident anthropogenic trace metal sources. Investigations on the element content of iron (Fe), arsenic (As), manganese (Mn), zinc ( $\mathrm{Zn})$, nickel $(\mathrm{Ni})$, copper $(\mathrm{Cu})$, lead $(\mathrm{Pb})$, cadmium $(\mathrm{Cd})$, cobalt $(\mathrm{Co})$, and mercury $(\mathrm{Hg})$ in different soil types developed in different geological parent materials have been carried out. The highest median concentrations of $\mathrm{Fe}$ and $\mathrm{Mn}$ were observed in soils belonging to ice-rich permafrost sediments formed during the Pleistocene (ice-complex) while the highest median values of $\mathrm{Ni}$, $\mathrm{Pb}$ and $\mathrm{Zn}$ were found in soils of both the ice-complex and the Holocene estuarine terrace of the Lena River delta region, as well as in the southernmost study unit of the hinterland area. Detailed observations of trace metal distribution on the micro scale showed that organic matter content, soil texture and iron-oxide contents influenced by cryogenic processes, temperature, and hydrological regimes are the most important factors determining the metal abundance in permafrostaffected soils. The observed range of trace element back-
\end{abstract}

ground concentrations was similar to trace metal levels reported for other pristine northern areas.

\section{Introduction}

Trace metals are naturally present in parent rock and in soils and occur in the form of sulfides, oxides, silicates, and carbonates. They can be adsorbed or bound to natural substances which may govern the elements' ability to migrate (Dube et al., 2001). The mechanisms of leaching and migration in soils vary for different trace metals (Niskavaara et al., 1997). For example, the transport of $\mathrm{Cu}$ to deeper soil layers mostly takes place when bound to organic substances, whereas $\mathrm{Ni}$ and some other elements like $\mathrm{Zn}, \mathrm{Cd}$ and $\mathrm{Pb}$, are generally transported as acid-mobilized, easily leachable compounds (Borg et al., 1989; Niskavaara et al., 1997). Trace metals are also one of the major groups of anthropogenic contaminants of soils. Arctic ecosystems belong to the most sensitive regions of the world with regard to effects of human impact (Weller, 1995; Gulinska et al., 2003). Examples for anthropogenic sources of trace metals in the Arctic are the Norilsk industry area in western Siberia and the mining industries of nickel, Monchegorsk and Zapolyarny, in the Kola Peninsula (Boyd et al., 2009; Jaffe et al., 1995; Niskavaara et al., 1997; Opekunova et al., 2007; Reimann et al., 1997; Zhulidov et al., 2011). Their activity leads to substantial pollution of Arctic ecosystems across several hundred kilometres (Zhulidov et al., 2011). Trace metals can reach the Arctic by different paths. Some studies demonstrate that the input of trace metals to the Arctic region including both natural and anthropogenic origin could be caused by long-range transport (Akeredolu 
et al., 1994; Barrie, 1985, 1985, 1992; Pacyna, 1995; Rahn et al., 1997; Rovinskiy et al., 1995; Thomas et al., 1992). However, data on the presence of contaminants in Arctic soils is limited in comparison with temperate or tropical regions. The evaluation of anthropogenic impacts on Arctic ecosystems requires knowledge on the background levels of trace metals as well as on the landscape distribution of elements in permafrost-affected soils in relation to soil properties.

One Arctic region commonly considered as pristine is the Lena River delta region (Nolting et al., 1996). The delta, being geomorphologically heterogeneous, acts as a natural filter that accumulates various materials transported by the Lena River from the south, including pollutants (Lisitsyn, 1994). Although the study area is remote, there exists a risk of airborne pollution by trace metals from anthropogenic sources connected to the settlements. The largest of these are the settlements Tiksi $\left(71^{\circ} 42^{\prime} 55.57^{\prime \prime} \mathrm{N}, 128^{\circ} 48^{\prime} 46.32^{\prime \prime} \mathrm{E}\right)$ and Kyusyur $\left(70^{\circ} 45^{\prime} 41.71^{\prime \prime} \mathrm{N}, 127^{\circ} 23^{\prime} 04.71^{\prime \prime} \mathrm{E}\right)$ (Fig. 1) (Rovinsky et al., 1995). The distribution of trace metals in water, marine sediments, air, vegetation and fauna of the delta has been studied in detail (Hölemann et al., 2005; Nolting et al., 1996; Presley, 1997). However, existing data on the presence of these substances in soils remains poorly studied.

Soil can function as a transport barrier by adsorbing contaminants and preventing their further migration to aquatic ecosystems, for example, through seepage water and groundwater (Dobrovol'skiy et al., 1986). However, consequences of climate change and anthropogenic impacts may affect main soil properties (e.g. carbon content, redox potential) leading to a modified migration ability of pollutants (Balbus et al., 2013; Dube et al., 2001; Weller, 1995).

Permafrost-affected soils are widespread in subarctic and Arctic tundra with great amounts of stored organic matter (Tarnocai et al., 2009). The mean soil organic carbon stock for the upper $1 \mathrm{~m}$ of soils of the Holocene terrace of the Lena River delta has been estimated to be $29 \mathrm{~kg} \mathrm{~m}^{-2} \pm 10 \mathrm{~kg} \mathrm{~m}^{-2}$ (Zubrzycki et al., 2013). Organic matter is capable of forming organo-mineral associations (Höfle et al., 2012) of the type that bind the majority of trace metals (Davranche et al., 2011; Dube et al., 2001). We assume that the predicted increase of global warming will intensify biogeochemical cycling within this large reservoir of carbon including bound trace elements in the upper layers of permafrost-affected soils.

The objectives of this paper are to investigate (1) the trace metal content in seasonally thawing layers of permafrostaffected soils of the Lena River delta region in northern Siberia, and (2) the landscape distribution of trace metals in soils of the Lena River delta and its hinterland by determining the relations between trace metal concentrations and important soil properties such as carbon and iron-oxide contents, soil texture, and thaw depth.

\section{Study area}

The investigation area is located in the northern part of eastern Siberia between $73.5^{\circ}$ and $69.5^{\circ} \mathrm{N}$. It covers the delta of the Lena River in the north and its nearby hinterland to the south (Fig. 1). The study area belongs to the Arcticsubarctic climate zone. The mean annual air temperature and the mean annual precipitation, measured by the meteorological station in Tiksi $\left(71^{\circ} 38^{\prime} \mathrm{N}, 128^{\circ} 52^{\prime} \mathrm{E}\right)$ during the $30 \mathrm{yr}$ period $1961-1990$, were $-13.6^{\circ} \mathrm{C}$ and $319 \mathrm{~mm}$, respectively (Roshydromet, 2011). The mean annual air temperature and annual precipitation of the region farther to the south, measured at the climate reference site in Dzhardzhan $\left(68^{\circ} 49^{\prime} \mathrm{N}\right.$, $\left.123^{\circ} 59^{\prime} \mathrm{E}\right)$ during the period $1998-2011$, was $-12.4^{\circ} \mathrm{C}$ and $298 \mathrm{~mm}$, respectively. The temperature amplitude at the Dzhardzhan reference site is higher than in Tiksi (Zubrzycki et al., 2012). Because of a strong continental climate in the study area, the summer period is longer and warmer in the region's south. The predominant winds in this area come from the north and north-east (http://meteo.infospace.ru, last access: 31.05.2013).

According to Grigoriev (1993), the Lena River delta area can be subdivided into three terraces and various floodplain levels of different ages. The first terrace including active floodplains (1-12 $\mathrm{m}$ above sea level) formed during the early Holocene and covers the main part of the eastern delta sector between the Tumatskaya and the Bykovskaya channels (Schwamborn et al., 2002). It is assumed to represent the "active" delta and was investigated at study location on Samoylov Island $\left(72^{\circ} 22^{\prime} \mathrm{N}, 126^{\circ} 31^{\prime} \mathrm{E}\right)$ and on Tit-Ary Island (site 1T-1) which is situated in the main Lena River channel south-east of Samoylov. Polygonal tundra is typical for the landscape units on both islands and is characterized by two different forms: polygon centres that are water-saturated and feature a large amount of organic matter due to accumulation under anaerobic conditions, and polygon rims that show evidence of cryoturbation in more or less all horizons of the active layer. They show a distinctly lower water table and less accumulation of organic matter (Fiedler et al., 2004; Kutzbach et al., 2004; Pfeiffer et al., 2002).

The investigations of the soils were mainly carried out on Samoylov Island in the southern-central Lena River delta. This site is representative for the younger delta areas including a Holocene estuarine terrace and various floodplain levels (Boike et al., 2013). The western part of the island represents the floodplain (site middle floodplain MF-1). Frequent changes of the river water level create different periods of sedimentation and result in the formation of stratified soils and sediment layers which are dominated either by mineral substrates with allochthonous organic matter or pure autochthonous peat (Boike et al., 2013). In contrast to the accumulative floodplain site, erosion processes dominate the eastern shores of the island and form an abrasion coast. This part is represented by an ancient estuarine (river-marine) terrace (sites 1T-Rim1 and 1T-Ce1), which covers about $70 \%$ of the 


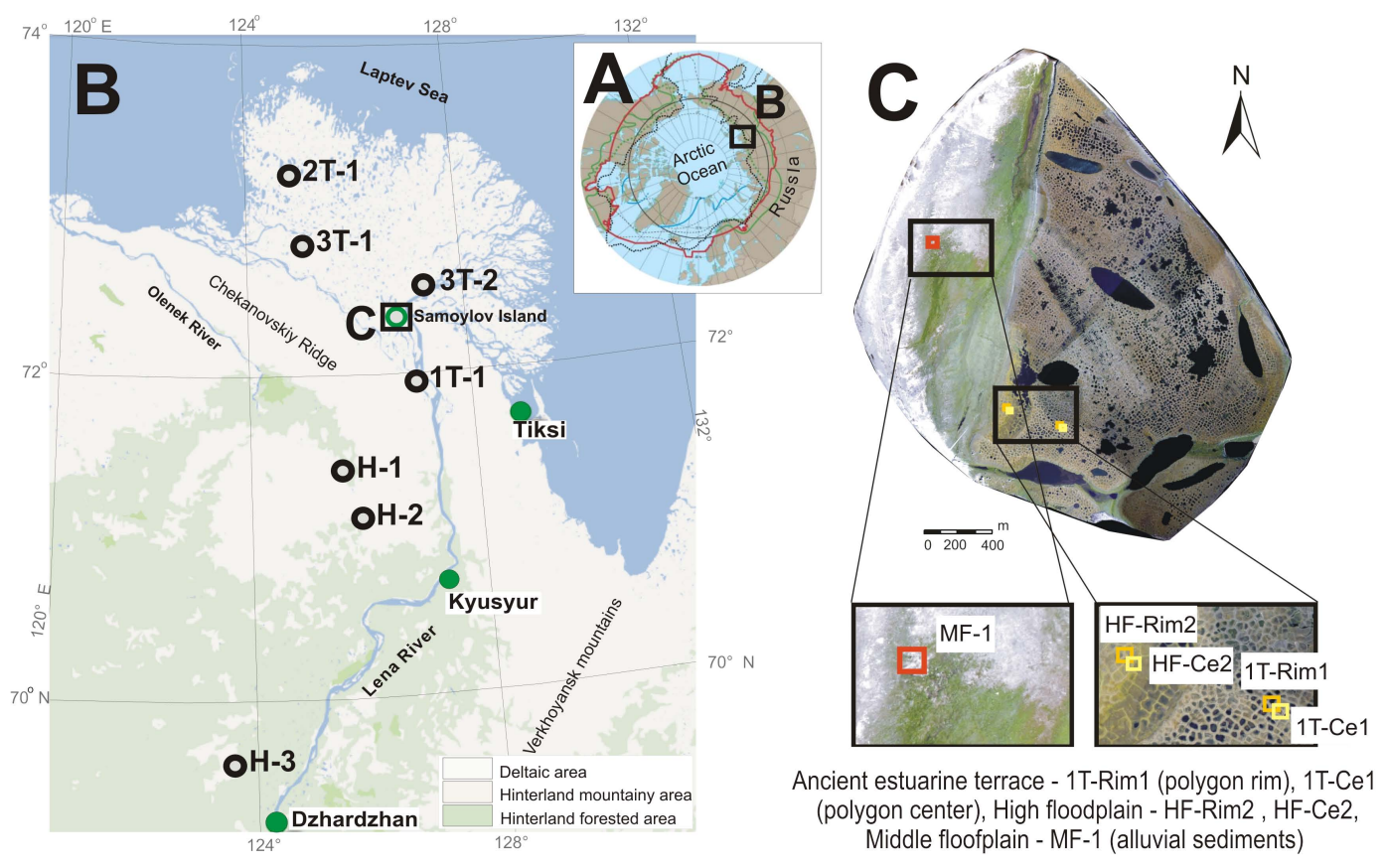

Fig. 1. (A) The position of the study area in the circum-Arctic, (B) an overview of the area in northern Siberia with location of study sites investigated in 2009, and (C) an overview of Samoylov Island with study site positions investigated in 2010. The maps are based on Google and Geocentre Consulting, AMAP and an orthorectified aerial picture of Samoylov, 2007 (SPARC-group, Alfred Wegener Institute, Potsdam).

total area of the island (Akhmadeeva et al., 1999). The high floodplain (sites HF-Rim2 and HF-Ce2) is fragmentarily situated between the east coast of the island and the western border of the estuarine terrace above the middle floodplain. This area could be described as a thermokarst depression of the terrace above the floodplain, because it is composed of the same layered plant detritus mixed with sand deposits of the ancient delta floodplain. It is inundated only at very exceptional annual floods (Akhmadeeva et al., 1999).

Arga Island (site 2T-1) is the northernmost site of the study area. It is located in the north-western part of the Lena River delta and represents a major part of the second terrace (20-30 m a.s.l.) of the delta (Schwamborn et al., 2002). This site is characterized by coarse-grained sandy sediments, which were formed from the late Pleistocene to late Holocene (Wagner, 2007).

The highest third terrace (30-55 m a.s.1.) was formed during the late Pleistocene and is exposed in the western and fragmentarily in the southern part of the delta (Schirrmeister et al., 2003). The deposits of that terrace consist of so-called ice complex enhanced by peat and sand accumulations overlying sequences of sandy sediments with a high content of segregated ice (Strauss et al., 2012). This geomorphological unit is represented by the Hardang-Sise Island in the west (3T-1) and the Sardakh Island in the south-east (3T-2) of the Lena River delta.

The investigation sites of the nearby hinterland are located on the slopes of the Chekanovsky Ridge (Fig. 1) on the west- ern side of the Lena River and represent instances of pronounced visible changes in vegetation cover (Zubrzycki et al., 2012). They represent the southern tundra (H-1), forest tundra (H-2), and northern taiga (H-3) landscape subzones.

The main soil forming process in these landscapes under investigation are soil organic matter accumulation, gleying and cryopedogenesis, which include freezing and thawing, frost stirring, mounding, fissuring, and solifluction. According to the soil taxonomy classification (Soil Survey Staff, 2010), we described all the soils studied as Gelisols (Table 2). The soils of the Arga Island (2T-1), Sardakh Island (3T-2), and Tit-Ary Island (1T-1) of the Lena River delta belong to the Turbel suborder. The soils of the studied site on HardangSise Island (3T-1) and sites of the hinterland H-1 $\left(73^{\circ} \mathrm{N}\right)$, H-2 $\left(70^{\circ} \mathrm{N}\right)$, and H-3 $\left(69^{\circ} \mathrm{N}\right)$ are described as Orthels. The studied sites of Samoylov Island belong to both Turbel and Orthel suborders. The soil of the study site 1T-Ce1 was described as Fibristel, which belongs to the Histel suborder. According to the Russian classification all soils of the units between $73^{\circ}$ and $70^{\circ} \mathrm{N}(\mathrm{H}-2)$ belong to the permafrost type (Table 2) (Yelovskaya, 1987; Desyatkin et al., 1991; Pfeiffer et al., 2000). The soil suborder at the southernmost site H-3 was determined to be a cryogenic soil (Yelovskaya, 1987). The soil properties of this unit differ from other soils of the Lena River delta and the area of the Chekanovsky Ridge slopes as it was developed underneath a forested area. 
Table 1. General field information of investigation sites.

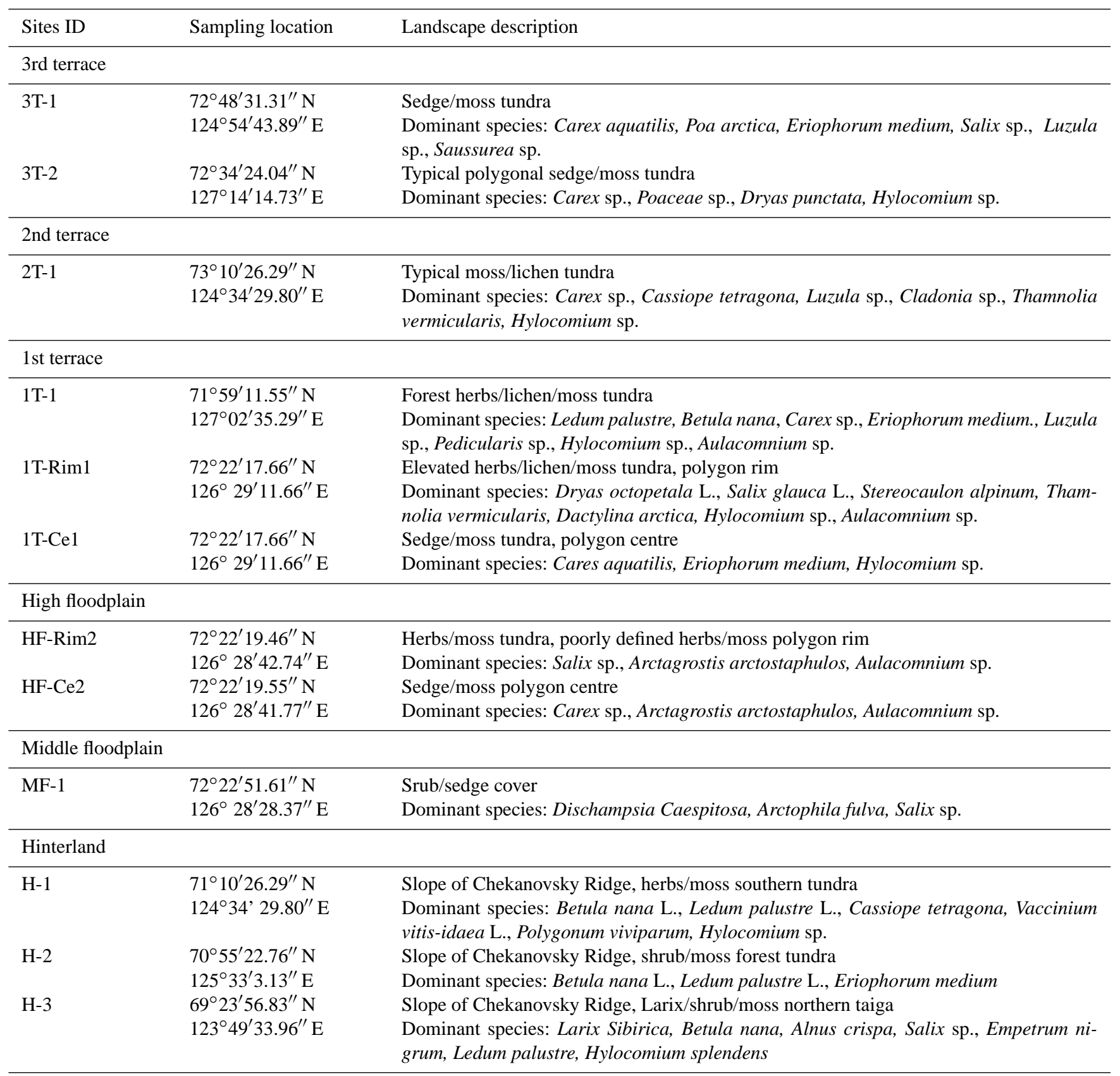

\section{Materials and methods}

The investigation site ID code, sampling location, and a brief landscape description are shown in Table 1. Field work was carried out in August 2009 and September 2010, when the seasonal thaw depth had reached its maximum as given in Table 2. Representative sites (13 soil profiles in total) for each unit of the study area were chosen and soil samples were taken from each genetic horizon of the thawed layer and stored in plastic bags. All soil types were determined according to both the US soil taxonomy (Soil Survey Staff, 2010) and the Russian classification of Yelovskaya (1987) (Table 2). The following soil characteristics were determined in the field: soil type, skeletal proportion, humus content, decomposition stage of organic matter, soil colour, texture shape and size, inclusions, bulk density, and root penetration. Macro- and microrelief forms, soil orders, anthropogenic changes, and vegetation cover with dominant species (Table 1) were described as well. The soil samples from the expedition in 2009 were preserved in thermo boxes without 
drying until they reached Germany for laboratory analyses. Because of difficulties with samples, cargo soils from the expedition in 2010 were air-dried prior to transport to the laboratory. The collected samples were analysed at the Institute of Soil Science (University of Hamburg, Germany).

Air-dried samples were sieved at $2 \mathrm{~mm}$ and analysed for soil acidity $(\mathrm{pH})$ in $\mathrm{H}_{2} \mathrm{O}$ extract (ratio $1: 2.5$ and $1: 25$ for soils with low and high organic carbon content, respectively; Bassler, 1997; DIN ISO 10390, 2005), electrical conductivity (CG 820 Schott Geraete GmbH, Germany; Cond 330i, WTW, Germany; DIN ISO 11265, 1997), water content (DIN 18121-1, 1998), and grain-size composition of the $<2$ mm fraction (Sedimat 4-12, UGT, Germany; DIN ISO $11277,2002)$. The homogenized sieved soil samples were ground and analysed for organic carbon (OC) and nitrogen (N) content (Vario MAX CNS Element Analyser, Germany; DIN ISO 10694, 1995). The pedogenic Fe and Mn compounds were extracted and fractioned by dithionite- and oxalate solutions (Mehra and Jackson, 1960; DIN 19684-6). To extract oxalate-soluble $\mathrm{Fe}$ and $\mathrm{Mn}, 100 \mathrm{~mL}$ of oxalate solution $\left(17.60 \mathrm{~g}(\mathrm{COOH})_{2}+28.40 \mathrm{~g}\left(\mathrm{COONH}_{4}\right)_{2}+1000 \mathrm{~mL}\right.$ bidistilled $\mathrm{H}_{2} \mathrm{O}$ ) was used. Dithionite-soluble $\mathrm{Fe}$ and $\mathrm{Mn}$ were extracted with $50 \mathrm{~mL}$ of complex solution A $(70.58 \mathrm{~g}$ $\mathrm{C}_{6} \mathrm{H}_{5} \mathrm{O}_{7} \mathrm{Na}_{3}+16.80 \mathrm{~g} \mathrm{NaHCO}_{3} \mathrm{~L}^{-1}+1000 \mathrm{~mL}$ bidistilled $\mathrm{H}_{2} \mathrm{O}$ ) and $20 \mathrm{~mL}$ of complex solution $\mathrm{B}\left(12.325 \mathrm{~g} \mathrm{MgSO}_{4}\right.$ $7 \mathrm{H}_{2} \mathrm{OL}^{-1}+1000 \mathrm{~mL}$ bidistilled $\mathrm{H}_{2} \mathrm{O}$ ). The resulting extracts were measured by flame atomic absorption spectrometry (AAS Varian AA 280 Series, Germany). The extraction of $\mathrm{Fe}, \mathrm{Mn}, \mathrm{Zn}, \mathrm{Cd}, \mathrm{Ni}, \mathrm{Cu}, \mathrm{As}, \mathrm{Pb}, \mathrm{Co}$ and $\mathrm{Hg}$, using aqua regia ( $\mathrm{HCl} 30 \%$ and $\mathrm{HNO}_{3} 60 \%$ ), was performed by a microwave method (Mars Xpress, CEM GmbH, Germany, DIN ISO 11466). The element content of $\mathrm{Cd}, \mathrm{Ni}, \mathrm{Cu}, \mathrm{As}, \mathrm{Pb}$, and Co was analysed using the AAS Varian AA 280 Series (Germany) with a graphite tube. The elemental content of $\mathrm{Fe}, \mathrm{Mn}$, and $\mathrm{Zn}$ was detected by flame with the AAS Varian AA 280 Series (Germany). The content of $\mathrm{Hg}$ was detected by the flow injection mercury system (FIMS) (Perkin Elmer AS 90; DIN ISO 16772:2005-06). Data quality was examined on a batch-by-batch basis for each element using standards, laboratory replicates and reagent blanks. Detection limits of each element (in $\mathrm{mg} \mathrm{kg}^{-1}$ ) are presented in Table 4.

We calculated volumetric trace metal concentrations $\mathrm{TM}_{\text {vol }}\left(\mathrm{g} \mathrm{m}^{-2} \mathrm{~cm}^{-1}\right)$ in $1 \mathrm{~cm}$-thick sections of the top and bottom horizons of studied units per square metre area using the formula

$\mathrm{TM}_{\mathrm{vol}}=\frac{C \times \mathrm{BD}}{d}$

, where $C$ is trace metal concentration in soil genetic horizon $\left(\mathrm{mg} \mathrm{kg}^{-1}\right), B D$ is the bulk density and $d$ is the soil genetic horizon depth.

Boxplot and scatterplot graphing was performed with the SPSS package version 20.0 based on methods of exploratory data analysis (Tukey, 1977). Prior to plotting, the element concentrations were log-transformed since the data were
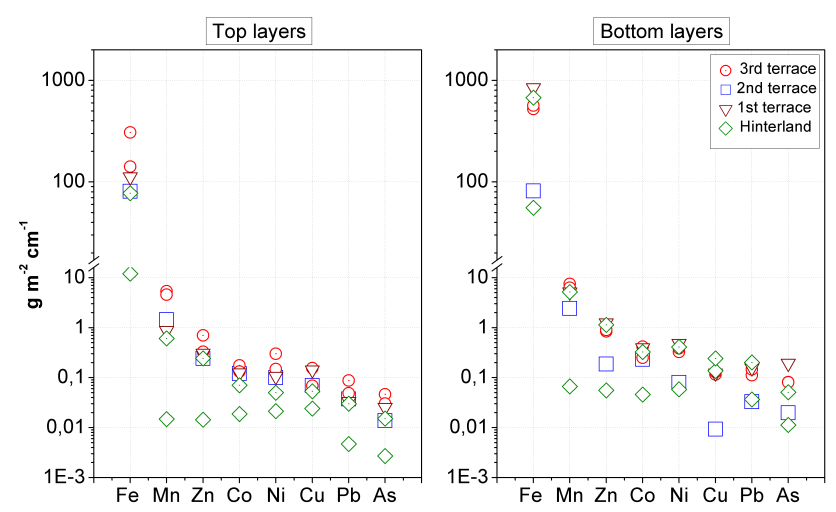

Fig. 2. Volumetric concentrations of trace elements in top and bottom soil horizons of investigated sites of the north-south transect in northern Siberia $\left(\mathrm{g} \mathrm{m}^{-2} \mathrm{~cm}^{-1}\right)$. Symbols with centred dot point out the sites 3T-1 and $\mathrm{H}-3$, respectively.

strongly right-skewed for the majority of the elements. Other graphs were produced with the OriginLab package version 8.6.

\section{Results and discussion}

\subsection{Physical and chemical soil properties}

Soils were characterized by slightly acidic and neutral conditions ( $\mathrm{pH}$ 4.0-6.2) excluding two units - 3T-1 and MF-1 (Table 3 ). For these sites, the $\mathrm{pH}$ was determined to be slightly alkaline ( $\mathrm{pH}$ values up to 7.4). The grain-size composition within all geomorphological units comprised mainly finegrained sand fractions (Table 3 ). The highest median value of the sand fraction was found on 2T-1. The third terrace (site 3T-2) showed the lowest fine-grained sand fraction content but significant silt fraction content. The unit H-3 was similar to the 3T-2 study site in terms of texture composition, as both consist primarily of the silt fraction. The data of $\mathrm{pH}$ and grain-size composition were similar to data reported for soils of the Lena River delta by Desyatkin et al. (1991).

The organic matter content showed a high spatial variability among all investigated units (Table 3 ) which has been also reported in other studies of the Arctic region (e.g. Bockheim et al., 2003). Median contents of carbon varied from $1 \%$ on the second terrace to $40 \%$ on the H-1 study site. The C:N ratio was higher for the sites located in the hinterland which could suggest a higher organic matter accumulation due to a slow process of organic matter decomposition.

Detailed results of standard soil parameters on Samoylov Island showed differences in their distribution on different microrelief forms. Polygon centres had a more acidic soil reaction than polygon rims. This difference is most evident for advanced stages of polygon development found on the first terrace. The highest median values of organic carbon content as well as of the $\mathrm{C}: \mathrm{N}$ ratio were observed for polygon 
Table 2. Soil classification of investigation sites according to Soil Survey Staff (2010) and to Russian soil classification (Yelovskaya, 1987).

\begin{tabular}{llll}
\hline Site ID & Thaw depth, cm & $\begin{array}{l}\text { Soil Survey } \\
\text { Staff (2010) }\end{array}$ & $\begin{array}{l}\text { Russian soil classification } \\
\text { (Yelovskaya, 1987) }\end{array}$ \\
\hline 3T-1 & 39.0 & Folistic Haplorthel & Permafrost Turfness-Gley Typical \\
3T-2 & 24.0 & Typic Aquorthel & Permafrost Silty-Peat-Gley \\
2T-1 & 57.0 & Typic Psammoturbel & Permafrost Alluvial Turfy Typical \\
1T-1 & 30.0 & Typic Aquiturbel & Permafrost Peatish-Gley Typical \\
1T-Rim1 & 61.0 & Typic Aquiturbel & Permafrost Turfness-Gley Typical \\
1T-Ce1 & 40.0 & Typic Fibristel & Permafrost Peat \\
HF-Rim2 & 40.0 & Typic Histoturbel & Permafrost Peatish-Gley \\
HF-Ce2 & 50.0 & Typic Histothel & Permafrost Peat-Gley \\
MF-1 & 91.0 & Typic Aquorthel & Permafrost Alluvial Turfness Typical \\
H-1 & $26.5 \pm 3.5$ & Ruptic Historthel & Permafrost Peat \\
H-2 & 39.0 & Typic Aquorthel & Permafrost Silty-Peat-Gley \\
H-3 & 49.0 & Typic Haplorthel & Cryogenic Soil \\
\hline
\end{tabular}

centres also indicating lower rates of organic matter decomposition there. The lowest contents of organic matter were observed in alluvial soils of the middle floodplain. The dominant fraction of mineral horizons of studied profiles was finegrained sand. The polygon rim 1T-Rim1 was of exceptional interest because the processes of cryoturbation were clearly pronounced. Here, median contents of clay and silt material within the soil profile were higher in comparison to the other study sites.

\subsection{Trace elements in soils}

\subsubsection{Element distribution within the north-south transect}

Results of trace element concentrations (median, minimum and maximum values) for all investigated geomorphological units are summarized in Table 4. The lowest median and minimum values of $\mathrm{Fe}, \mathrm{As}, \mathrm{Cu}, \mathrm{Ni}, \mathrm{Pb}$, and $\mathrm{Zn}$ were found in the study site $2 \mathrm{~T}-1$ of the second terrace. The southernmost site $\mathrm{H}-3$ of the north-south transect was characterized by highest median values of $\mathrm{Pb}, \mathrm{Cu}$, and $\mathrm{Zn}$. Geographical environments (vegetation cover, temperature and precipitation) might affect the soil formation and development processes and influence on element distribution within the soil profile of this studied area. High median concentrations of these elements were also observed in the units located on the first and the third terrace. The study sites of the third terrace were notably different from the other units by showing highest median contents of Mn suggesting more advanced soil development processes. Cd content was under the detection limit for the 3T-2 study site whereas the highest median was detected for the study site $\mathrm{H}-1$ of the hinterland area. All investigated sites were characterized by very low concentrations of $\mathrm{Hg}$ which were close to the detection limit.

The comparison of our results with studies reported for other northern regions (presented in Table 5) showed higher median values of $\mathrm{Fe}, \mathrm{As}, \mathrm{Co}$ and $\mathrm{Zn}$ for all our study sites except for study site 2T-1. Median contents of Mn for the units of the third terrace were higher than for Gleysols (FAO, 2006) reported by Salminen et al. (2004), however the range of $\mathrm{Mn}$ in all investigated units coincided with the reported values of other studies. A wider range and higher medians of $\mathrm{Ni}$, As and $\mathrm{Zn}$ were comparable to the data reported by Rovinsky et al. (1995) for tundra Gleysols of the lowest Lena River area. For study sites 1T-Ce1 and H-1, which were characterized by an accumulation of organic matter in their profiles, the median concentrations of $\mathrm{Cu}$ were higher than the values found for Histosols (FAO, 2006) of the eastern Barents region (Salminen et al., 2004), and of organic soil layers in eastern Baltic region (Salminen et al., 2011). Because of limited geochemical data for the Siberian region, and despite different approaches of trace element extraction methodology, we compared our results with the data given by Zhulidov et al. (1997a, b). The maximum contents of $\mathrm{Cu}$ in our investigated units were lower than values reported for pristine wetlands of north-eastern Siberia. The maximum concentrations of $\mathrm{Cd}, \mathrm{Cu}, \mathrm{Pb}$, and $\mathrm{Zn}$ for all studied soils were much lower than the values reported for anthropogenically affected areas of western Siberia. The minimum concentrations of $\mathrm{Cd}$ coincide with the values reported for polygonal bog peat of the background area in western Siberia (Table 5, data source 5). However, the minimum contents of $\mathrm{Cu}, \mathrm{Pb}$, and $\mathrm{Zn}$ for all soil profiles except for the study site 2T-1 were higher than the data reported by Zhulidov et al. (1997a). Concentrations for the majority of metal elements in soils of this study were similar to element levels in soils of remote areas in the Usa River basin (Walker et al., 2003), and the Pechora River basin, north-east European Russia (Walker et al., 2006ab, 2009). Resembling values for $\mathrm{Cu}, \mathrm{Hg}, \mathrm{Mn}, \mathrm{Pb}$, and $\mathrm{Zn}$ were found in soils of this study as well when compared to concentrations in pristine soils from the subarctic region of Labrador, Canada (Walker, 2012). 
Table 3. Min-max range (numerator) and median values (denominator) of standard soil characteristics of all studied units along the northsouth transect.

\begin{tabular}{|c|c|c|c|c|c|c|c|}
\hline \multirow[t]{2}{*}{ Sites ID } & \multirow[t]{2}{*}{$\mathrm{pH}$} & \multicolumn{3}{|c|}{ Texture $(\%)$} & \multirow[t]{2}{*}{$\mathrm{C}(\%)$} & \multirow[t]{2}{*}{$\mathrm{N}(\%)$} & \multirow[t]{2}{*}{$\mathrm{C}: \mathrm{N}$ ratio } \\
\hline & & Clay & Silt & Sand & & & \\
\hline \multicolumn{8}{|l|}{ 3rd terrace } \\
\hline \multirow[t]{2}{*}{$3 \mathrm{~T}-1\left(n=2^{1}\right) o^{2}$} & $\underline{6.0-7.0}$ & 20.0 & 75.0 & 4.7 & $\underline{2.50-8.40}$ & $\underline{0.20-0.57}$ & $\underline{12.6-14.8}$ \\
\hline & $\overline{6.5}$ & & & & 5.42 & 0.38 & 13.7 \\
\hline \multirow[t]{2}{*}{$3 \mathrm{~T}-2(n=2) o$} & $\underline{4.0-5.0}$ & 21.0 & 65.0 & 14.0 & $\underline{2.50-8.32}$ & $\underline{0.15-0.50}$ & $\underline{16.6-16.7}$ \\
\hline & 4.5 & & & & 5.39 & 0.32 & 16.7 \\
\hline \multicolumn{8}{|l|}{ 2nd terrace } \\
\hline \multirow{2}{*}{$2 \mathrm{~T}-1\left(n=4^{1}\right) t$} & $\underline{4.0-5.0}$ & $\underline{2.0-5.0}$ & $\underline{1.0-16.0}$ & $80.0-97.0$ & $\underline{0.14-3.32}$ & $\underline{0.01-0.19}$ & $\underline{10.4-17.5}$ \\
\hline & 5.0 & 4.08 & 4.54 & 91.1 & 1.06 & 0.68 & 15.5 \\
\hline \multicolumn{8}{|l|}{ 1st terrace } \\
\hline \multirow{2}{*}{$1 \mathrm{~T}-1(n=3) t$} & $\underline{4.0-5.0}$ & $\underline{22.0-27.0}$ & $\underline{44.0-46.0}$ & $\underline{27.0-34.0}$ & $\underline{1.46-8.03}$ & $\underline{0.10-0.38}$ & $\underline{14.5-21.4}$ \\
\hline & $\overline{5.0}$ & 24.4 & $\overline{45.0}$ & $\overline{30.5}$ & $\overline{1.85}$ & $\overline{0.13}$ & 14.8 \\
\hline \multirow{2}{*}{ 1T-Rim1 $(n=6) t$} & 5.6-6.6 & $\underline{4.0-9.0}$ & $\underline{22.0-52.0}$ & $\underline{41.0-73.0}$ & $\underline{0.91-4.12}$ & $\underline{0.07-0.26}$ & $12.8-20.6$ \\
\hline & 6.2 & 6.6 & 27.9 & 65.5 & 2.80 & 0.18 & 15.2 \\
\hline \multirow{2}{*}{$1 \mathrm{~T}-\mathrm{Ce} 1(n=4) h$} & $\underline{5.4-5.5}$ & n.d. & n.d. & n.d. & 5.92-11.7 & $\underline{0.17-0.42}$ & $27.6-34.6$ \\
\hline & 5.5 & & & & 8.39 & 0.24 & 34.0 \\
\hline \multicolumn{8}{|l|}{ High floodplain } \\
\hline \multirow[t]{2}{*}{ HF-Rim2 $(n=5) t$} & 5.6-6.9 & $2.0-6.0$ & 5.0-27.0 & $66.0-94.0$ & $\underline{0.30-11.3}$ & $\underline{0.03-0.34}$ & $10.4-33.5$ \\
\hline & 6.1 & 3.9 & 21.6 & 74.6 & 1.31 & 0.10 & 13.4 \\
\hline \multirow{2}{*}{$\mathrm{HF}-\mathrm{Ce} 2(n=4) o$} & $\underline{5.8-6.2}$ & $\underline{4.0-5.0}$ & $\underline{13.0-27.0}$ & $\underline{68.0-83.0}$ & $\underline{1.12-15.9}$ & $\underline{0.07-0.49}$ & $14.2-36.0$ \\
\hline & $\overline{5.9}$ & 4.2 & $\overline{20.0}$ & 75.8 & 6.75 & 0.26 & 20.5 \\
\hline \multicolumn{8}{|l|}{ Middle floodplain } \\
\hline \multirow{2}{*}{ MF-1 $(n=8) o$} & 7.0-7.4 & $\underline{2.0-10.0}$ & $\underline{1.0-60.0}$ & $\underline{30.0-97.0}$ & $\underline{0.30-4.01}$ & $\underline{0.03-0.22}$ & $\underline{11.3-22.2}$ \\
\hline & 7.2 & 4.0 & 10.2 & 85.8 & 1.43 & 0.09 & 14.2 \\
\hline \multicolumn{8}{|l|}{ Hinterland } \\
\hline \multirow[t]{2}{*}{$\mathrm{H}-1(n=5) o$} & $3.0-4.0$ & n.d. & n.d. & n.d. & $35.0-48.0$ & $\underline{1.51-2.13}$ & $18.9-26.3$ \\
\hline & 4.0 & & & & 40.0 & $\overline{1.83}$ & 19.3 \\
\hline \multirow[t]{2}{*}{$\mathrm{H}-2(n=5) o$} & $\underline{3.0-4.0}$ & $\underline{10.0-12.0}$ & $\underline{29.0-33.0}$ & $\underline{55.0-61.0}$ & $\underline{1.20-38.6}$ & $\underline{0.08-1.05}$ & $15.1-36.9$ \\
\hline & 4.0 & 11.1 & 31.1 & 57.7 & 7.1 & 0.38 & 18.5 \\
\hline \multirow[t]{2}{*}{$\mathrm{H}-3(n=3) o$} & $\underline{4.0-6.0}$ & $\underline{21.0-22.0}$ & $\underline{62.0-63.0}$ & $\underline{14.0-17.0}$ & $2.17-17.7$ & $\underline{0.10-0.59}$ & $18.7-30.0$ \\
\hline & 5.0 & 21.5 & 62.6 & 15.9 & 2.21 & 0.12 & 21.7 \\
\hline
\end{tabular}

${ }^{1} n$-number of the measurements; ${ }^{2} o-$ Orthel soil suborder, $t$ - Turbel soil suborder, $h$ - Histel soil suborder; n.d. - not determined.

Effects from human activity can be substantial in close vicinity to contamination sources (Jaffe et al., 1995; Zhulidov et al., 1997b; Ziganshin et al., 2011; Walker et al., 2003) but also remote from them (Akeredolu et al., 1994; Thomas, 1992). To detect presumable anthropogenic element additions to soil ecosystems the ratio of trace elements in top and bottom soil horizons is used. However, as some studies show (Reimann et al., 2008; Sucharova et al., 2012) this technique cannot be beneficial in all cases. Usually the top layers are organic-rich and reflect the biogeochemical cycle at the earth surface. They differ significantly from the minerogenic layers which mainly reflect mineralogical de- velopments during weathering, and, as in our investigation area, frost processes. In order to provide a clear idea of the vertical distribution of trace metals within the soil profiles of the north-south transect, we calculated the trace metal concentrations per soil volume in the top and bottom soil horizons (Fig. 2). In all cases the bottom soil horizons contain slightly higher volumetric amounts of all measured trace elements in contrast to the top soils (except the element $\mathrm{Cu}$ for the study site 2T-1). This finding is most evident in Fe distribution for studied sites of the third terrace, first terrace (site 1T-1) and the hinterland (site H-3). The western side's valley belt along the Lena River between $72^{\circ}$ and $67^{\circ} \mathrm{N}$ belongs 
Table 4. Range (min-max) (numerator) and median values (denominator) of the trace metals in $\mathrm{mg} \mathrm{kg}^{-1}$ determined in the soils of investigated units in northern Siberia and detection limits.

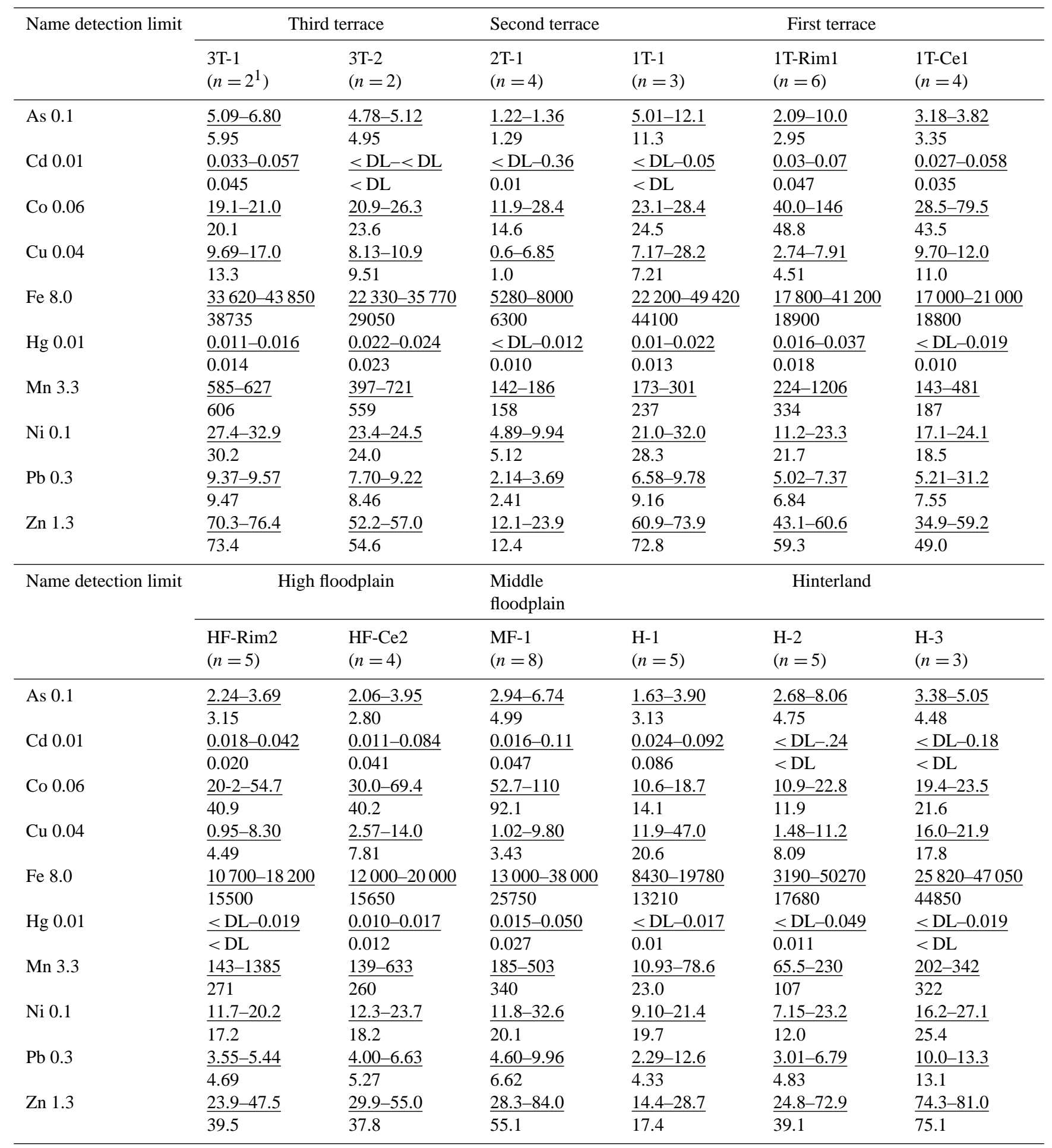

${ }^{1} n$-number of the measurements; DL - detection limit.

to the so-called litho-chalcophile structural-formational complex (Geological Atlas of Russia, Saint Petersburg, 1996). This area is characterized by high content of sulfide min- erals (elements including $\mathrm{Pb}, \mathrm{Zn}, \mathrm{Cu}, \mathrm{Hg}$, and $\mathrm{As}$ ). It is characterized by high element accumulation coefficients $R_{k}$ which range from 2.5 to 5 . These observations support the 
Table 5. Range (min-max) (numerator) and median values (denominator) of the trace metal concentrations reported for soil types of the eastern Barents region, the Baltic region, the lower Lena River area, north-eastern Siberia, and western Siberia.

\begin{tabular}{|c|c|c|c|c|c|c|c|c|c|c|c|}
\hline \multirow[t]{2}{*}{ Soil type } & \multirow[t]{2}{*}{ Data source } & \multicolumn{10}{|c|}{ Element $\mathrm{mg} \mathrm{kg}^{-1}$} \\
\hline & & As & $\mathrm{Cd}$ & Co & $\mathrm{Cu}$ & $\mathrm{Fe}$ & $\mathrm{Hg}$ & $\mathrm{Mn}$ & $\mathrm{Ni}$ & $\mathrm{Pb}$ & $\mathrm{Zn}$ \\
\hline Gleysols* & 1 & $\frac{0.44-12.0}{4.50}$ & $\frac{0.005-0.292}{0.063}$ & $\frac{1.38-52.8}{8.31}$ & $\frac{1.03-59.3}{9.42}$ & $\frac{2690-47200}{16300}$ & - & $\frac{31.1-5020}{377}$ & $\frac{2.82-682}{20.1}$ & $\frac{0.52-8.55}{3.29}$ & $\frac{0.50-87.9}{30.6}$ \\
\hline \multirow[t]{2}{*}{ Histosols* } & & $\underline{0.05-30.8}$ & $\underline{0.005-0.33}$ & $\underline{0.50-33.6}$ & $\underline{0.50-152}$ & $\underline{259-77000}$ & - & $\underline{3.18-3280}$ & $1.00-49.5$ & $\underline{0.30-15.8}$ & $\underline{0.50-93.6}$ \\
\hline & & $\frac{1.04}{1.04}$ & 0.027 & 4.70 & 8.80 & 11300 & & 122 & 11.3 & 1.81 & 15.8 \\
\hline \multirow[t]{2}{*}{ Fluvisols* } & & $\underline{0.05-15.1}$ & $\underline{0.005-0.34}$ & $\underline{0.50-23.0}$ & $\underline{0.50-28.0}$ & 646-34 200 & - & $11.2-3480$ & $1.00-73.4$ & $\underline{0.43-8.88}$ & $2.65-65.5$ \\
\hline & & 1.73 & 0.026 & 7.28 & $\overline{13.0}$ & 13000 & & 274 & 17.5 & 2.99 & 26.0 \\
\hline \multirow{2}{*}{ Organic soil layer } & 2 & $0.25-17.8$ & $\underline{0.08-3.18}$ & $0.29-12.6$ & $2.85-87.3$ & $767-21400$ & $\underline{0.04-0.42}$ & $23.6-4880$ & $1.54-131$ & $6.52-361$ & $7.70-90.9$ \\
\hline & & 1.56 & $\overline{0.40}$ & $\overline{1.16}$ & 7.60 & 2890 & 0.20 & $\overline{265}$ & 5.06 & $\overline{31.1}$ & 20.0 \\
\hline \multirow[t]{2}{*}{ Tundra Gleysols } & 3 & $\underline{0.02-0.78}$ & $\underline{0.03-0.40}$ & - & $\underline{0.72-5.02}$ & - & $\underline{0.01-0.04}$ & - & $\underline{0.72-4.96}$ & - & $\underline{6.80-18.9}$ \\
\hline & & 0.22 & 0.12 & & 2.50 & & 0.02 & & 2.60 & & 13.0 \\
\hline Hydric soils & 4 & - & $\underline{0.05-0.81}$ & - & $\underline{2.70-63.0}$ & - & - & - & - & $\underline{1.80-44.0}$ & $\underline{4.40-137}$ \\
\hline Sedge-moss peat & & - & $\begin{array}{l}- \\
\underline{0.03-0.48} \\
-\end{array}$ & - & $\frac{\overline{3.0-62.0}}{-}$ & - & - & - & - & $\frac{-}{1.90-23.0}$ & $\begin{array}{l}- \\
.00-96.0 \\
-\end{array}$ \\
\hline Hydric soils & 5 & - & $\underline{0.05-56.0}$ & - & $\underline{1.70-664}$ & - & - & - & - & $\frac{1.90-288}{-}$ & $\underline{4.60-920}$ \\
\hline Polygonal bog peat & & - & $\underline{0.05-64.0}$ & - & $\frac{1.50-442}{-}$ & - & - & - & - & $\frac{1.50-274}{-}$ & $\frac{12.0-878}{-}$ \\
\hline
\end{tabular}

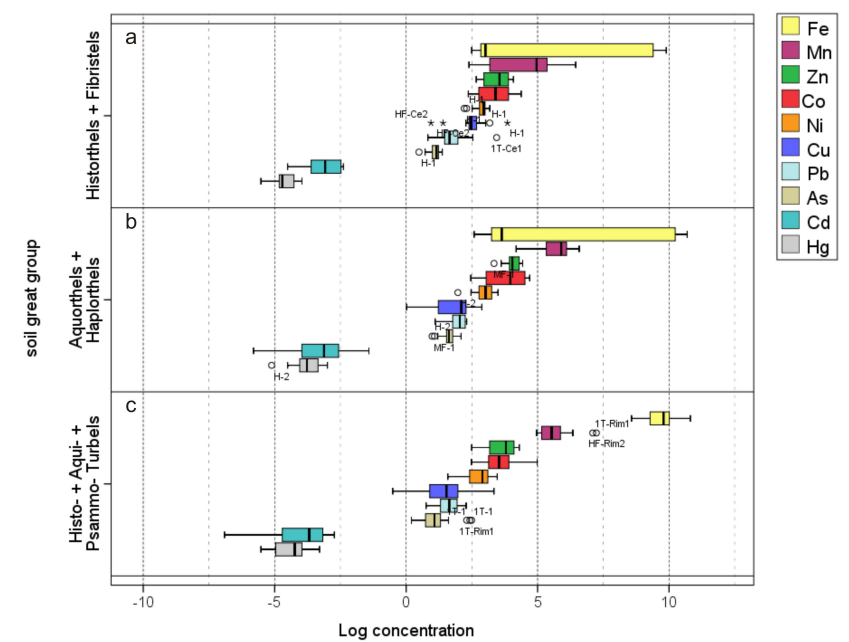

Fig. 3. Log-boxplot comparison of gravimetric concentration levels (in $\mathrm{mg} \mathrm{kg}^{-1}$ ) and variations of 10 elements in soil great groups based on three soil suborders Turbels, Histels and Orthels. Note that concentrations for all elements were log-transformed prior to plot.

hypothesis of a geological origin for those trace elements at our study sites. The volumetric concentrations of elements $\mathrm{Ni}, \mathrm{Cu}, \mathrm{Co}$, and $\mathrm{Pb}$ in the top $1 \mathrm{~cm}$-thick layers were found to be very close to the values observed for watersheds of the Yenisey River delta area, about $300 \mathrm{~km}$ from the Norilsk mining industry (Korobova et al., 2003).

\subsubsection{Element distribution within the great soil groups}

The investigated soils of the area in northern Siberia belong to the following great groups of the Turbel suborder: Histoturbels, Aquiturbels, and Psammoturbels. The Orthel suborders consist of three great soil groups: Aquorthels, Historthels, and Haplorthels. The suborder of Histels includes only one great soil group called Fibristels. To reveal differences in trace elements' distribution in studied soils, we combined the great soil groups for each of the determined soil suborders of the US soil taxonomy (Soil Survey Staff, 2010) according to organic carbon content. Figure 3 shows a logboxplot graph of the 10 trace elements' distribution for each of the determined soil group. The first combined group which includes Historthels and Fibristels (Fig. 3a) with a higher organic matter content (up to $40 \%$ ) is characterized by higher medians and smaller ranges of values for $\mathrm{Ni}$ and $\mathrm{Cu}$, and by a higher median value and bigger range of the Mn content. The second group shown in Figure $3 \mathrm{~b}$ represents the soils of the Orthels with median carbon content of $8 \%$. In this group, the distribution of $\mathrm{Fe}$ is characterized by high variability similar as in the first group described above. However, the distribution of $\mathrm{Co}, \mathrm{Cu}$, and $\mathrm{Cd}$ has a wider range than in the organic-rich soils. The third combined group including all kinds of Turbels with a median value of $2 \%$ organic carbon was generally characterized by higher scatter of element contents except for $\mathrm{Mn}$ and especially Fe. A notably higher median value of $\mathrm{Fe}$ concentration was detected in the Turbels suborder. 
a

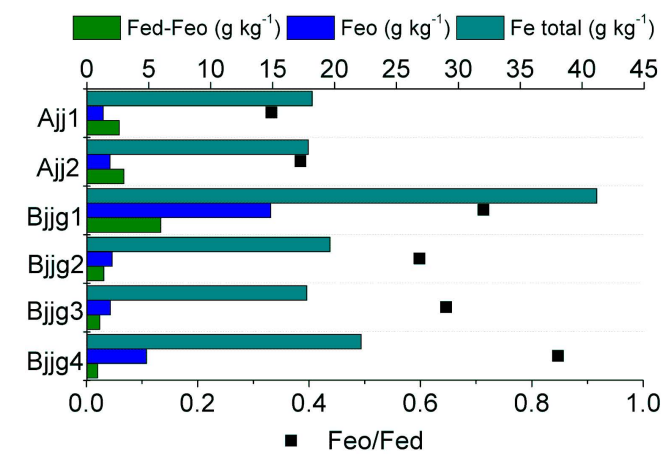

b

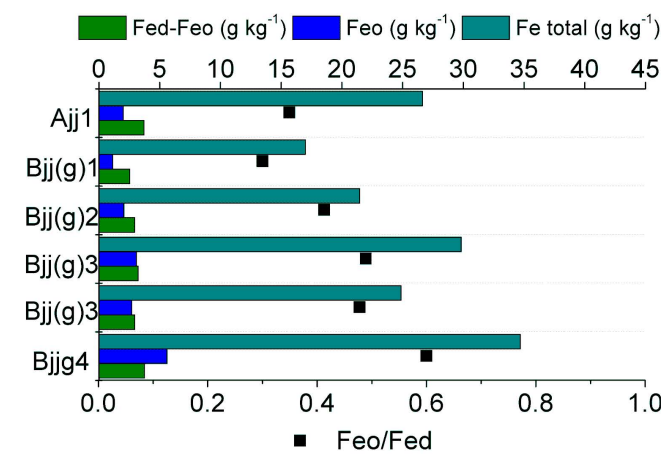

Fig. 4. Vertical distribution of Fe in soils of polygon rim 1T-Rim1 of the ancient estuarine terrace (a) and alluvial soils of the middle floodplain MF-1, (b) where $\mathrm{Fe}_{d}$ is a well crystallized form of iron oxides, $\mathrm{Fe}_{o}$ is a poorly crystallized form of iron oxides and $\mathrm{Fe}_{\text {total }}$ is the amount of iron in soil extracted by aqua regia.
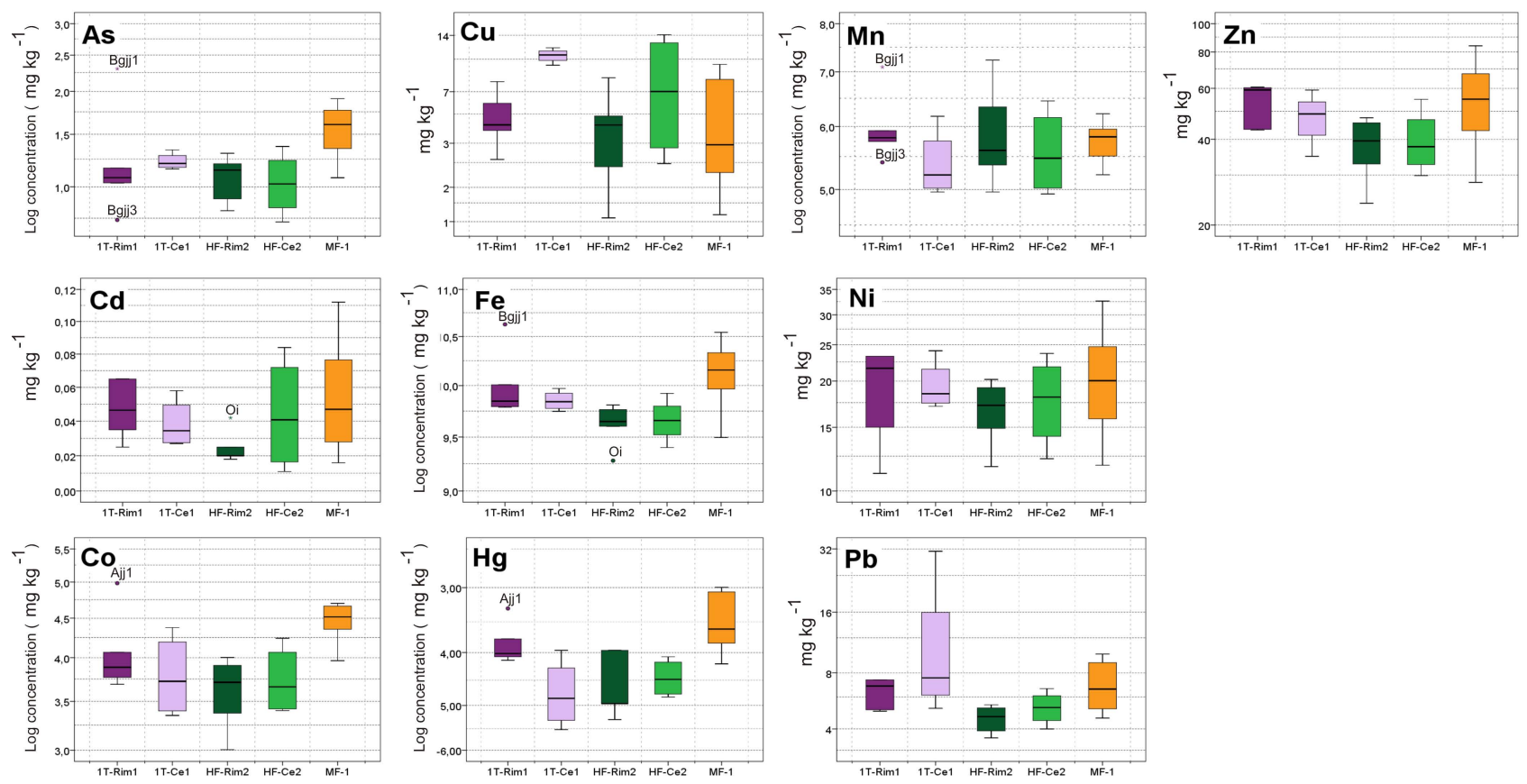

Fig. 5. Boxplot comparison of element distribution (in $\mathrm{mg} \mathrm{kg}^{-1}$ ) in soils of Samoylov Island. Note that the values of $\mathrm{As}, \mathrm{Co}, \mathrm{Fe}, \mathrm{Hg}$, and $\mathrm{Mn}$ were log-transformed prior to plot.

\subsubsection{Element distribution in topographic units of Samoylov Island}

The amount and distribution of iron oxides in soils are known to influence soil properties such as anion adsorption, surface charges, specific surface area, aggregate formation, nutrient transformation and pollutants retention in soils. In permafrost-affected soils $\mathrm{Fe}$ is accumulated in the unfrozen horizons (Boike et al., 1999; Fiedler et al., 2004) and is likely to be discharged with water during freezing and thawing processes to Fe-rich streams. Later, these processes might cause the mobilization of other elements and their further migration and accumulation within the active layer of the soil profile. The ratio of different iron-oxide fractions can be used to evaluate environmental conditions and the processes of modern pedogenesis in permafrost-affected soils (Zubrzycki et al., 2008). Higher values of the iron-oxide ratio were found in the bottom part of the investigated profiles on Samoylov Island. This finding is probably related to less pronounced processes of pedogenesis due to the prevalence of anoxic conditions. The ratio between the so-called "active" iron oxide, the oxalate-soluble part $-\mathrm{Fe}_{\mathrm{o}}$, and well crystallized forms of iron oxides, the dithionite-soluble fraction $-\mathrm{Fe}_{\mathrm{d}}$, was higher in the bottom part of 1T-Rim1 (Fig. 4). This higher ratio could 

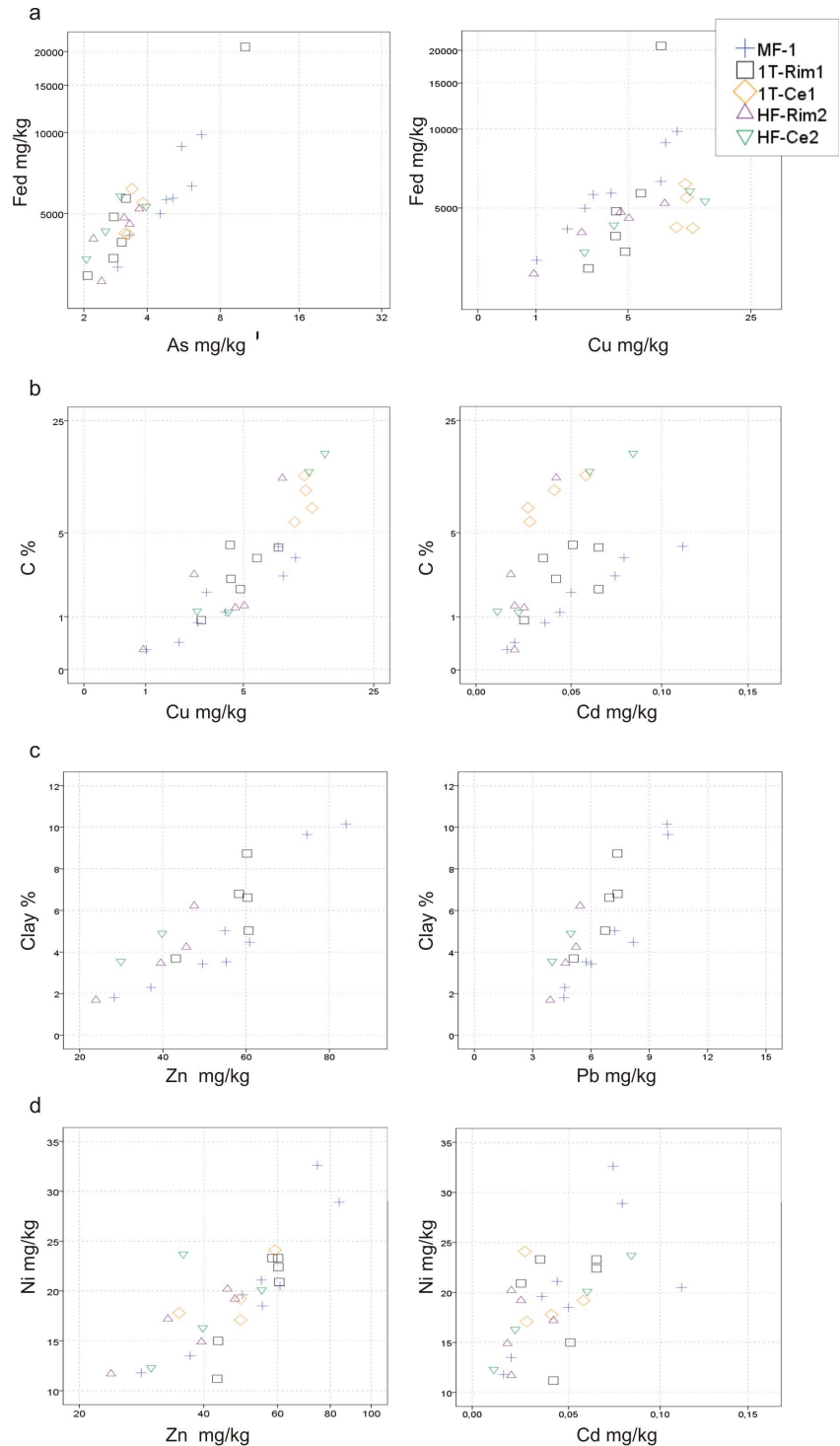

Fig. 6. Scatterplots showing the interrelation between the selected elements and the general soil properties in the soil profiles of Samoylov Island. ((a) - correlation between the elements and a well crystallized form of iron oxide, (b) - the elements and organic carbon content, (c) - the elements and clay content, and (d) - correlation between the elements).

be explained by intensive mixing of mineralogical particles and organic compounds within the soil profile of polygon rim due to cryoturbation. As a result, with the increase of the organic matter content within the subsoil the amorphous forms of iron oxides $\left(\mathrm{Fe}_{\mathrm{o}}\right)$ could form stable $\mathrm{Fe}$-organic complexes.

The results comparing element levels within and between the soil profiles are displayed graphically by boxplots using trace metal values from Table 4 in Fig. 5. The highest median values of $\mathrm{Fe}, \mathrm{Co}$, and As were found for MF-1. Higher content of $\mathrm{Fe}$ could be explained by additional input of allochthonous material during annual flooding. According to
Adriano (1986), Co is an element that accumulates in the hydrous oxides of $\mathrm{Fe}$, as well as As which usually has a tendency to form insoluble compounds with iron. The site of the middle floodplain was also characterized by higher variability of $\mathrm{Fe}, \mathrm{Zn}, \mathrm{Ni}$ and $\mathrm{Cd}$. As Co, the elements $\mathrm{Zn}$ and $\mathrm{Ni}$ are found to be easily adsorbed by iron hydroxides (Salminen et al., 2004). An enrichment of the elements Mn, Fe, As and $\mathrm{Co}$ at the cryoturbated polygon rim (site 1T-Rim1) was found in the layer of a distinct visible band of $\mathrm{Fe}$ accumulation. This accumulation was caused by element redistribution at the capillary fringe in these groundwater-affected soils (Fiedler et al., 2004).

Detailed comparison of polygonal landscape microforms revealed differences in element distribution between the polygon rims and polygon centres. Higher median values and less variability of $\mathrm{Mn}$ were found within the elevated part (site 1T-Rim1) of polygons in contrast to low-centred parts (site 1T-Ce1) of the first terrace polygon. Such a difference may be explained by redox and hydraulic gradient as described in detail by Fiedler et al. (2004) (upward translocation). The maximum content of Mn was detected on study site HF-Rim2 at a poorly elevated polygon rim. Manganese nodules found at a depth of $29-35 \mathrm{~cm}$ could indicate the occurrence of seasonal redox changes (precipitation of $\mathrm{Mn}$ ions as manganese hydro(oxides) with increasing oxygen level). It is interesting to note that the highest median content and smallest range of $\mathrm{Cu}$ were observed for the most organic-rich soil of 1T-Ce1 belonging to the low-centred part of a polygon. It was shown in several studies (Adriano, 1986; KabataPendias, 2001) that organic-enriched surface horizons contain higher concentrations of $\mathrm{Cu}$, than lower soil horizons which contain less organic matter. The investigated sites which belong to the high and middle floodplains were characterized by a much higher range of $\mathrm{Cu}$ distribution within the profiles compared to the first terrace soil profiles. A smaller range of $\mathrm{Cu}$ in 1T-Rim1 soil profile was likely caused by more pronounced homogeneity (mixing of organic matter with mineralogical material) within the soil layers. The polygon centre 1T-Ce1 also differed from other sites by having a high median and the widest variability of $\mathrm{Pb}$ content. The maximum $\mathrm{Pb}$ content for this soil was observed in the subsurface horizon. We cannot provide a clear-cut interpretation of this phenomenon but different processes might cause this distribution. $\mathrm{Pb}$ compounds found in soils are quite immobile (Salminen, 2004). However, some investigations showed that solubilization of $\mathrm{Pb}$ could be attributed to the soluble chelate complex formation with organic matter (Stevenson et al., 1979). So the observed distribution of $\mathrm{Pb}$ might be caused by a combination of the dominant species (Carex Aquatilis, Wahlenb.) root uptake and downward movement as soluble chelate complexes with organic matter. Another reason might be the cumulative influence of seasonal freezing and thawing cycles and formation of ice lens (Overduin et al., 1997). As a result, a solute is excluded from soil matrix and, due to 
convective water transport to the freezing front, accumulates in subsurface horizons.

Relationships between the trace metal contents and soil properties were evaluated by means of scatterplots (Reimann et al., 2008). Some selected examples of element distribution dependence from the observed soil characteristics are given in Fig. 6. The elements As and $\mathrm{Cu}$ showed a tendency to associate with well crystallized iron-oxide forms. Evans (1989) claimed that $\mathrm{Cu}$ has a stronger tendency to form associations with oxide forms of $\mathrm{Fe}$, relative to other metals. It also holds true for the behaviour of As mediated by the presence of iron oxides (Adriano, 1986; Selim, 2011). A positive correlation of element concentrations with increasing organic matter content was found for the elements $\mathrm{Cu}$ (study sites MF-1, 1T-Rim1, 1T-Ce1) and Cd (sites MF-1 and 1T-Ce1). The elements $\mathrm{Zn}$ and $\mathrm{Pb}$ mainly coincided with clay content in soils. However, the role of insoluble organic materials (in case of polygon centre sites) and the oxides of $\mathrm{Fe}$ and Mn cannot be ignored. A tendency to positive correlation between $\mathrm{Ni}$ and $\mathrm{Fe}, \mathrm{Ni}$ and $\mathrm{Pb}, \mathrm{Ni}$ and $\mathrm{Zn}$, and $\mathrm{Ni}$ and $\mathrm{Cd}$ was observed. The scatterplots for the last two element pairs are shown in Fig. 6d.

All investigated sites were characterized by a slight concentration increase of the majority of trace metal above the permafrost table in a gleyic layer. This was more pronounced for the elements $\mathrm{Zn}$ and $\mathrm{Ni}$ at the study site 1T-Rim1 and for $\mathrm{Mn}, \mathrm{Fe}$, and As in the soil profile of MF-1. A similar trend for the distribution of these elements was observed for permafrost-affected soils of tundra landscapes in the Yenisei River delta (Korobova et al., 2003) and in studies of Fiedler et al. (2004). This similarity supports the suggestion that the presence of the permafrost table could cause this increase by acting as a geochemical barrier to further trace metal dislocation within the soil profile.

\section{Conclusions}

The first measurements of trace metal concentrations in permafrost-affected soils of fluvial landscapes of the Lena River delta in northern Siberia generally showed a high scatter in landscape element distribution. The northernmost unit (2T-1) of the transect was characterized by low values of the majority of measured trace metals, whereas the investigation sites of the first (1T-1) and the third terrace of the Lena River delta and one unit located in the hinterland (H-3) were characterized by similar higher amounts of most trace elements. The highest median content of total $\mathrm{Cu}$ and $\mathrm{Cd}$ was found at the site $\mathrm{H}-1$. This finding we gear to increasing affinity between the elements, $\mathrm{Cu}$ and $\mathrm{Cd}$, and high organic matter content determined in soils of this unit. Based on the US taxonomic soil classification approach, differences in trace metal distribution within the soil suborders were found. Log-boxplot comparison of element distribution observed in the studied soils showed differences particularly in Fe and
Mn distribution between Turbels with a lower organic matter content, and Orthels and Histels characterized by higher amounts of carbon in their profiles.

We have revealed that microrelief features can influence element distribution in natural permafrost-affected soils by the example of Samoylov Island. Higher concentrations of most metals were observed in the soil profile MF-1 at the middle floodplain compared to the other sites. This finding suggested that, apart from the parent material, the second potential source of trace metals at the middle floodplain could be allochthonous substance input during annual flooding. Comparison of the elevated polygon rims and water saturated polygon centres in an ancient estuarine terrace and a high floodplain showed that values of the trace metals $\mathrm{Cu}$ and $\mathrm{Pb}$ were higher in polygon centres which are characterized by an accumulation of organic matter and more moist environments. Higher concentrations of some elements (e.g. Fe, Mn, $\mathrm{Ni}$, As, and $\mathrm{Zn}$ ) were detected in most soil profiles in the deeper minerogenic soil horizons compared to the top soil. This supported our suggestion that the permafrost table, acting as a geochemical barrier, retarded further migration of elements into deeper horizons. Besides factors such as organic carbon content, soil texture, and iron oxides, cryoturbation processes, temperature, and soil water regimes play a significant role in landscape distribution of trace metals within the studied profiles of permafrost-affected soils, and could not be overlooked.

We cannot eliminate the possibility that pollution of Arctic ecosystems occurs due to long-range transport. However, our research showed that the concentrations of all the investigated metals were similar to those reported for other pristine northern regions. We concluded that the studied area in northern Siberia is pristine and can serve as a reference region for determining human influences on permafrostaffected landscapes or comparing similar pristine areas in the Arctic region. However, the existing dataset needs to be expanded. The processes of deposition, accumulation, leaching, translocation, and transformation of trace metals in permafrost-affected soils need to be studied in greater detail in order to estimate possible risks from both factors (climate change and anthropogenic pollution) on Arctic ecosystems.

\section{Supplementary material related to this article is available online at http://www.biogeosciences.net/11/1/ 2014/bg-11-1-2014-supplement.pdf.}

Acknowledgements. This study was supported by the State Research Center - Arctic and Antarctic Research Institute, St. Petersburg, Russia, the University of Hamburg, and funded by the Cluster of Excellence "CliSAP" (EXC177), by the German Research Foundation (DFG). The dissertation fellowship of I. Antcibor was funded by the University of Hamburg (HmbNFG) 
and by the German Academic Exchange Service (DAAD). We would like to thank all Russian and German colleagues who helped us during the fieldwork. The authors particularly appreciate Monika Voß and Andreas Behr for the assistance in trace metal content measurements, and Christian Wille and Benjamin Runkle for valuable advice and ideas during the preparation of this manuscript.

Edited by: I. Bussmann

\section{References}

Adriano, D. C.: Trace elements in the terrestrial environment, Springer-Verlag New-York Inc., 1986.

Akeredolu, F. A., Barrie, L. A., Olson, M. P., Oikawa, K. K., Pacyna, J. M., and Keeler, G. J.: The flux of anthropogenic trace metals into the Arctic from the mid-latitudes in 1979/80, Atmos. Environ., 28, 1557-1572, 1994.

Akhmadeeva, I., Becker, H., Friedrich K., Wagner, D., Pfeiffer, E.M., D., Quass, W., Zhurbenko, M., Zollner E., and Boike, J.: Modern Processes in Permafrost Affected soils, in: Expeditions in Siberia 1998, edidet by: Rachold, V. and Grigoriev, M. N., Reports on Polar Research, 31, 19-80, 1999.

Alekseev, Y. V.: Heavy metals in soils, Leningrad, "Agropromizdat", 1987 (in Russian).

Balbus, J. M., Boxall, A. B. A., Fenske, R. A., McKone, T. E., and Zeise, L.: Implications of global climate change for the assessment and management of human health risks of chemicals in the natural environment, Environ. Toxicol. Chem., 32, 62-78, 2013.

Barrie, L. A.: Five years of chemistry observations in the Canadian Arctic. Atmos. Environ. Serv., 19, 1995-2010, 1985.

Barrie, L. A.: Arctic air pollution: an overview of current knowledge, Atmos. Environ. Serv., 20, 643-663, 1986.

Barrie, L. A., Gregor, D., Hargrave, B., Lake, R., Muir, D., Shearer, R., Tracey, B., and Bildeman, T.: Arctic contaminants: sources, occurrence and pathways, Sci. Total Environ., 122, 1-74, 1992.

Bassler, R. (Ed.): Methoden. Die untersuchung von Böden. VDLUFA-Verlag, Darmstadt, 1997.

Bockheim, J. G., Hinkel, K. M., and Nelson, F. E.: Prediction carbon storage in Tundra soils of Arctic Alaska, Soil Sci. Soc. America, 67, 934-940 pp, 2003.

Boike, J. and Overduin, P. P.: Seasonal changes in hydrology, energy and chemistry in the active layers of arctic tundra soils in Taimur Peninsula, Russia, in: Land ocean systems in the Siberian Arctic: dynamic and history, edited by: Kassens, H., Bauch, H. A., Dmitrenko, I., Eicken, H., Hubberten, H.-W., Melles, M., Thiede, J., and Timokhov, L., Berlin, Springer, 229-236, 1999.

Boike, J., Kattenstroth, B., Abramova, K., Bornemann, N., Chetverova, A., Fedorova, I., Fröb, K., Grigoriev, M., Grüber, M., Kutzbach, L., Langer, M., Minke, M., Muster, S., Piel, K., Pfeiffer, E.-M., Stoof, G., Westermann, S., Wischnewski, K., Wille, C., and Hubberten, H.-W.: Baseline characteristics of climate, permafrost and land cover from a new permafrost observatory in the Lena River Delta, Siberia (1998-2011), Biogeosciences, 10, 2105-2128, doi:10.5194/bg10-2105-2013, 2013.

Boyd, R., Barnes, S-J., De Caritat, P., Chekushin, V., Melezhik, V., Reimann, C., and Zientek, M.: Emissions from the copper-nickel industry on the Kola Peninsula and at Noril'sk, Russia, Atmos. Environ., 43, 1474-1480, 2009.

Davranche, M., Grybos, M., Gruau, G., Pedrot, M., Dia, A., and Marcas, R.: Rare earth element patterns: A tool for identifying trace metal sources during wetland soil reduction, Chem. Geol., 284, 127-137, 2011.

Desyatkin, R. and Teterina, L.: Soils of the Lena River Delta. Genesis and irrigation of soils in Yakutia, Edited volume, Yakutsk, 55-66, 1991.

DIN 18121-1: Soil, investigation and testing - Water content Part 1: Determination by drying in oven, (DIN 18121-1:1998), 1998.

DIN ISO 10390: Soil quality: Determination of $\mathrm{pH}$ (DIN ISO 10390:2005), 2005.

DIN ISO 10694: Soil quality: Determination of organic and total carbon after dry combustion (elementary analysis) (DIN ISO 10694:1995), 1995.

DIN ISO 11277: Soil quality: Determination of particle size distribution in mineral soil material - Method by sieving and sedimentation (DIN ISO 11277:1998 + ISO 11277:1998 Corrigendum 1:2002), 2002.

DIN ISO 11466: Soil quality: Extraction of trace elements soluble in aqua regia (DIN ISO 11466:1995), 1995.

DIN 19684-6: Methods of soil investigations for agricultural engineering - Chemical laboratory tests - Part 6: Determination of iron soluble in oxalate solution (DIN 19684-6:1997), 1997.

Dobrovol'skiy, G. V. and Nikitin, E. D.: Ecological functions of soil, Moscow, p. 108, 1986.

Dube, A., Zbytniewski, R., Kowalkowski, T., Curkowska, E., and Buszewski, B.: Adsorption and migration of heavy metals in soil, Polish J. Environ. Studies, 10, 1-10, 2001.

Evans, L. J.: Chemistry of metal retention by soils, Environ. Sci. Technol., 23, 1046-1056, 1989.

Fiedler, S., Wagner, D., Kutzbach, L., and Pfeiffer, E.-M.: Element redistribution along hydraulic and redox gradients of lowcentered polygons, Lena Delta, Northern Siberia, Soil Sci. Soc. Am., 1002-1011, 2004.

Grigoriev, M. N: Cryomorphogenesis in the Lena Delta. Yakutsk: Permafrost Institute Press, 176 pp., 1993 (in Russian).

Gulinska, J., Rachlewiez, G., Szczucinski, W., Baralkiewiez, D., Kozka, M., Bulska, E., and Burzyk, M.: Soil contamination in High Arctic of human impact, Central Spitsbergen, Svalbard, Polish J. Environ. Studies, 12, 701-707, 2003.

Höfle, S., Rethemeyer, J., Mueller, C. W., and John, S.: Organic matter composition and stabilization in a polygonal tundra soil of the Lena Delta, Biogeosciences, 10, 3145-3158, doi:10.5194/bg10-3145-2013, 2013.

Hölemann, J. A., Schirmacher, M., and Prange, A.: Seasonal variability of trace metals in the Lena River and the southeastern Laptev Sea: Impact of the spring freshet, Glob. Planet. Change, 48, 112-125, 2005.

Isaev, A. S.: Trace elements in boreal forests, Moscow, "Nauka", 2004 (in Russian).

Jaffe, D., Cerundolo, B., Rickers, J., Stolzberg, R., and Baklanov, A.: Deposition of sulfate and heavy metals on the Kola Peninsula, Sci. Total Environ. 160/161, 127-134, 1995.

Kabata-Pendias, A.: Trace elements in soils and plants, $3^{r d}$ edition, by CRC Press LLC, 2001 (in Russian). 
Korobova, E. M., Ukraintseva, N. G., Surkov, V. V., and Brown, J. B.: Geochemical study of the tundra landscapes in the Yenisey delta and gulf area, Permafrost, Phillips, Springman \& Arenson, Swets and Zeitlinger Lisse, 601-606, 2003.

Kutzbach, L., Wagner, D., and Pfeiffer, E.-M.: Efferct of microrelief and vegetation on methane emission from wet polygonal tundra, Lena Delta, Northern Siberia, Biogeochemistry , 69, 341-362, 2004.

Lisitsyn, A. P.: Marginal filter of oceans, Mar. Geol., 34., 735-747, 1994 (in Russian).

Mehra, O. P. and Jackson, M. L.: Iron oxide removal from soils and clays by dithionite-citrate systems buffered with sodium bicarbonate, 7th National Conference on Clays and Clay Minerals, p. 317, 1960.

Nikonov, V. V. and Lukina, N. V.: Biogeochemical cycles in north areas under air pollution, part 1, part 2, Apatity, 1996 (in Russian).

Niskavaara, H., Reimann, C., Chekushin, V., and Kashulina, G.: Seasonal variability of total and easily leachable element contents in topsoils $(0-5 \mathrm{~cm})$ from eight catchments in the European Arctic (Finland, Norway and Russia), Environ. Pollut., 96, 261274, 1997.

Nolting, R. F., van Dalen, M., and Helder, W.: Distribution of trace and major elements in sediment and pore waters of the Lena Delta and Laptev Sea, Mar. Chem. 53, 285-299, 1996.

Opekunova, M., Elsukova, E, Chekushin, V., Tomilina, O., Salminen, R., Reimann, C., and Antcibor, I.: Monitoring of environmental changes in the impact zone of "Severonickel" smelter using methods of bioindication, Vestnik of St. Petersburg State University., Ser. 7., No. 1, 71-79, 2007 (in Russian).

Overduin P. P. and Young K. L.: The effect of freezing on soil moisture and nutrient distribution at Levinson-Lessing Lake, Taymyr Peninsula, Siberia, in: the proceedings of the International Symposium on Physics, Chemistry, and Ecology of Seasonaly Frozen Soils, Iskandar IK, edited by: Wright, E. A., Radke, J. K., Sharratt, B. S., Groenevelt, P. H., and Hinzman, L. D., University of Alaska Press, Fairbanks, Alaska, 327-333, 1997.

Pacyna, J. M.: The origin of Arctic air pollutants: lessons learned and future research, Sci. Total Environ. 160/161, 39-53, 1995.

Pfeiffer, E.-M., Wagner, D., Becker, H., Vlasenko, A., Kutzbach, L., Boike, J., Quass, W., Kloss, W., Schulz, B., Kurchatova, A., Pozdnyakov, V., and Akhmadeeva, I.: Modern processes in permafrost affected soils, Reports on Polar and marine Research, 354, 22-54, 2000.

Pfeiffer, E.-M., Wagner, D., Kobabe, S., Kutzbach, L., Kurchatova, A., Stoof, G., and Wille, C.: Modern processes in permafrost affected soils, Reports on Polar and Marine Research 426, 21-24, 2002.

Presley, B. J.: A review of Arctic trace metal data with implications for biological effects, Mar. Pollut. Bullet., 35, 226-234, 1997.

Rahn K. A., Tomza U., and Khodzher T. V.: An event of long-range transport of Siberian aerosol to Tiksi, Russia, J. Aerosol Sci., Elsevier Science, 28, Suppl. 1, s465-s466, 1997.

Reddy, K. R. and DeLaune, R. D.: Biochemistry of wetlands, science and applications, Taylor \& Francis Group, 2008.

Reimann, C., Boyd, R., de Caritat, P., Halleraker, Jo. H., Kashulina, G., Niskavaara, H., and Bogatyrev, I.: Topsoil (0-5 cm) composition in eight arctic catchments in Northern Europe (Finland, Norway and Russia), Environmental pollution, 95, 45-56, 1997.
Reimann, C., Filzmoser, P., Garrett, R., and Dutter, R.: Statistical data analysis explained (Applied environmental statistics with R), John Wiley \& Sons, Ltd, 2008.

Roshydromet: 2011.08.08. Russian Federal Service for Hydrometeorology and Environmental Monitoring, http://www. worldweather.org, 2011.

Rovinsky, F., Pastuchov, B., Bouyvolov, Y., and Burtseva, L.: Present day state of background pollution of the natural environment in the Russian Arctic in the region of the Ust-Lena Reserve, Sci. Total Environ. 160/161 193-199, 1995.

Russian Federation Committee on Geology and use of mineral resources, A.P. Karpinsky All-Russian Geological Research Institute (VSEGEI), State Russian Federation Committee of higher education, Saint-Petersburg State Mining Institute (SPGGI), Geochemical Map of Russia 1:10 000 000, Geological Atlas of Russia, Section II: Geological structure and geophysical characteristics of earth interior, Saint-Petersburg, 1996.

Salminen, R., Chekushin, V., Tenhola, M., Bogatyrev, I., Glavatskikh, S.P., Fedotova, E., Gregorauskiene, V., Kashulina, G., Niskavaara, H., Polischuok, A., Rissanen, K., Selenok, L., Tomilina, O., and Zhdanova, L.: Geochemical Atlas of the Eastern Barents Region, Elsevier, 548 pp., 2004.

Salminen, R., Chekushin, V., Gilucis, A., Gregorauskiene, V., Petersell, V., and Tomilina O.: Distribution of Elements in Terrestrial Mosses and the Organic Soil Layer in the Eastern Baltic Region, Geological survey of Finland, Special paper 50, 116 pp., 2011.

Schirrmeister, L., Grosse, G., Schwamborn, G., Andreev, A. A., and Meyer, H.: Late quaternary history of the accumulation plain north of the Chekanovsksy Ridge (Lena Delta, Russia): a multidisciplinary approach, 2003.

Schwamborn, G., Rachold, V., and Grigoriev, M. N.: Late Quaternary sedimentation history of the Lena Delta, The Journal of the International Union for Quaternary Research, Quaternary International, 89, 119-134, 2002.

Server "Pogoda Rossii" http://meteo.infospace.ru (last access: 31.05.2013), 2013.

Soil Survey Staff: Keys to Soil Taxonomy, United States Department of Agriculture \& Natural Resources Conservation Service, Washington, DC, 322 pp., 2010.

Stevenson, F. J. and Welch, L. F.: Migration of applied lead in a field soil, Environ. Sci. Technol., 13, 1255-1259, 1979.

Strauss, J., Schirrmeister, L., Wetterich, S., Borchers, A., and Davydov, S.: Grain-size properties and organic carbon stock of northeast Sibarian Ice Complex (Yedoma) permafrost, Glob. Biogeochem. Cy., 26, 12 pp., 2012.

Sucharova, J., Suchara, I., Hola, M., Marikova, S., Reimann, C., Boyd, R., Filzmoser, P., and Englmaier, P.: Top-/bottom-soil ratios and enrichment factors: What do they really show?, Appl. Geochem., 27, 138-145, 2012.

Tarnocai, C., Canadell, J.G., Schuur, E.A.G., Kuhry, P. Mazhitova, G., and Zimov, S.: Soil organic carbon pools in the northern circumpolar permafrost region, Global Biogeochem. Cy. , 23, 11 pp., 2009.

Thomas, D. J., Tracey, B., Marshall, H., and Norstrom, R. J.: Arctic terrestrial ecosystem contamination, Sci. Total Environ., Elsevier Science Publishers, 122, 135-164, 1992.

Tukey, J. W., Exploratory data analysis, Addison-Wesley, Reading, MA, USA, 1977. 
Wagner, D., Gattinger, A., Embacher, A., Pfeiffer, E.-M., Schloter, M., and Lipski, A.: Methanogenic activity and biomass in Holocene permafrost deposits of the Lena Delta, Siberian Arctic and its implication for the global methane budget, Glob. Change Biol., 13, 1089-1099, 2007.

Walker, T. R.: Comparison of anthropogenic metal deposition rates with excess soil loading from coal, oil and gas industries in the Usa Basin, NW Russia, Polish Polar Res., 26, 299-314, 2005.

Walker, T. R.: Properties of selected soils from the sub-Arctic region of Labrador, Canada, Polish Polar Res., 33, doi:10.2478/v10183012-0013-4, 2012.

Walker, T. R., Young, S. D., Crittenden, P. D., and Zhang, H.: Anthropogenic metal enrichment of snow and soil in Northeastern European Russia, Environmental Pollution, 121, 11-21, 2003.

Walker, T. R., Crittenden, P. D., Young, S. D., and Prystina, T.: An assessment of pollution impacts due to the oil and gas industries in the Pechora basin, north-eastern European Russia, Ecol. Indicators, 6, 369-387, 2006a.

Walker, T. R., Habeck, O., Karjalainen, T. P., Virtanen, T., Solovieva, N., Jones, V., Kuhry, P., Pomonorov, V. I., Mikkola, K., Nikula, A., Patova, E. Crittenden, P. D., Young, S. D., and Ingold, T.: Perceived and measured levels of environmental pollution: interdisciplinary research in the subarctic lowlands of northeast European Russian, Ambio., 35, 220-228, 2006 b.

Walker, T. R., Crittenden, P. D., Dauvalter, V. A., Jones, V., Kuhry, P., Loskutova, O., Mikkola, K., Nikula, A., Patova, E. Pomonorov, V. I., Pystina, T., Rätti, O., Solovieva, N., Stenina, A., Virtanen, T., and Young, S. D.: Multiple indicators of human impacts on the environment in the Pechora Basin, north-eastern European Russia, Ecol. Indicators, 9, 765-779, 2009.

Weller, G.: Global pollution and its effect on the climate of the Arctic, Sci. Total Environ., 160/161, 19-24, 1995.
World reference base for soil resources: a framework for international classification, correlation and communication, Food and Agriculture organization of the united nation (FAO), Rome, 2006

Yelovskaya, L. G.: Classification and diagnostics of frozen soils of Yakutia, USSR Academy of Sciences, 171 pp., 1987 (in Russian).

Ziganshin, R. A., Voronin, V. I., and Karbainov, Y. M.: Forest ecosystem monitoring in Taimyr, Vestnik KrasGAU, 8, 117-123, 2011 (in Russian).

Zhulidov, A. V., Headley, J. V., Robarts, R. D., Nikanorov, A. M., Ischenko, A. A., and Cham, M. A.: Concentrations of Cd, Pb, Zn and $\mathrm{Cu}$ in Pristine Wetlands of the Russian Arctic, Mar. Pollut. Bullet., Elsevier Science, 35, 242-251, 1997a.

Zhulidov, A. V., Headley, J. V., Robarts, R. D., Nikanorov, A. M., Ischenko, A. A., and Cham, M. A.: Concentrations of Cd, Pb, Zn and $\mathrm{Cu}$ in Contaminated Wetlands of the Russian Arctic, Mar. Pollut. Bullet., Elsevier Science, 35, 252-259, 1997 b.

Zubrzycki, S., Wetterich, S., Schirrmeister, L., Germogenova, A., and Pfeiffer, E.-M.: Iron-oxides and pedogenesis of modern gelisols and paleosols of the southern Lena Delta, Siberia, Russia, in: Proceedings of the 9th International Conference on Permafrost, edited by: Kane, D. L. and Hinkel, K. M., Univ. Alaska Fairbanks, Institute of Northern Engineering, 2095-2100, 2008.

Zubrzycki, S., Kutzbach, L., Vakhrameeva, P., and Pfeiffer, E.M.: Variability of Soil Organic Carbon Stocks of Different Permafrost Soils: Initial Results from a North-South Transect in Siberia, in: Proceedings of the 10th International Conference on Permafrost, edited by: Hinkel, K. M., Salekhard, 485-490, 2012.

Zubrzycki, S., Kutzbach, L., Grosse, G., Desyatkin, A., and Pfeiffer, E.-M.: Organic carbon and total nitrogen stocks in soils of the Lena River Delta, Biogeosciences, 10, 3507-3524, doi:10.5194/bg-10-3507-2013, 2013. 